Women in Middle

Eastern History 
This page intentionally left blank 


\title{
Women in Middle
}

\section{Eastern History}

\author{
Shifting Boundaries
}

in Sex and Gender

EDITED BY

NIKKI R. KEDDIE

BETHBARON

Yale University Press

New Haven and London 
Copyright (C) 1991 by Yale University. All rights reserved.

This book may not be reproduced, in whole or in part, including illustrations, in any form (beyond that copying permitted by Sections 107 and 108 of the U.S. Copyright Law and except by reviewers for the public press), without written permission from the publishers.

Designed by Sonia L. Scanlon.

Set in Palatino type by

The Composing Room of Michigan, Inc.

Printed in the United States of America

\section{Library of Congress \\ Cataloging-in-Publication Data}

Women in Middle Eastern history :

shifting boundaries in sex and gender/ edited by Nikki R. Keddie and Beth Baron.

p. $\mathrm{cm}$.

Includes index.

ISBN 0-300-05005-4 (cloth)

0-300-05697-4 (pbk.)

1. Women-Middle East-History.

I. Keddie, Nikki R. II. Baron, Beth.

HQ1726.5.W66 1992

305.42'0956-dc20

The paper in this book meets the guidelines for permanence and durability of the Committee on Production Guidelines for Book Longevity of the Council on Library Resources. 